\title{
Zaburzenia lipidowe u pacjentów z rakiem jamy ustnej i leukoplakią - przegląd piśmiennictwa
}

\section{Lipid profile disorders in oral cancer and oral precancerous conditions - a literature review}

\author{
${ }^{1}$ Klinika Chirurgii Czaszkowo-Szczękowo-Twarzowej, Chirurgii Jamy Ustnej i Implantologii \\ Warszawski Uniwersytet Medyczny \\ 2 Zakład Stomatologii Zintegrowanej, Warszawski Uniwersytet Medyczny
}

DOI: http://dx.doi.org/10.20883/df.2017.23

\begin{abstract}
Streszczenie
Podwyższony poziom cholesterolu i związane z nim ryzyko wystąpienia choroby niedokrwiennej serca jest zjawiskiem powszechnie znanym. Celem pracy jest przedstawienie przeglądu piśmiennictwa dotyczącego zaburzeń lipidowych u pacjentów ze stanami przedrakowymi i rakiem jamy ustnej oraz zwrócenie uwagi na inny aspekt zaburzeń lipidowych. Niski poziom cholesterolu może być czynnikiem ryzyka dla wystąpienia choroby nowotworowej lub efektem przebiegu choroby. Zmiany w profilu lipidowym zostały powiązane z procesem chorobowym ze względu na funkcję, jaką pełnią lipidy w tworzeniu nowych komórek. Badacze opisują obniżenie poziomu lipidów i lipoprotein u pacjentów z rakiem jamy ustnej i uważają, że zaburzenia profilu lipidowego u tych chorych są konsekwencją procesu chorobowego, a nie jego przyczyną, jako że przebieg procesu chorobowego może ograniczać przyjmowanie pokarmów. Zauważono również obniżenie poziomu niektórych składowych lipidogramu u chorych ze stanami przedrakowymi.
\end{abstract}

Słowa kluczowe: rak jamy ustnej, leukoplakia, lipidy, lipoproteiny.

\begin{abstract}
Elevated cholesterol levels and the associated risk of ischemic heart disease are a well-known phenomenon. The aim of this paper is to review the literature on lipid disorders in patients with oral precancerous conditions and oral squamous cell carcinoma and to draw attention to another aspect of lipid disorders. Low cholesterol levels may be a risk factor for the onset of cancer or the outcome of a disease. Changes in the lipid profile have been linked to the disease process because of the function that lipids play in the formation of new cells. Researchers describe a decrease in lipid and lipoprotein levels in patients with oral cancer, and believe that lipid profile disorders in these patients are a consequence of the disease process rather than its cause as the course of the disease process may limit the intake of food. A decrease in the level of some components of the lipidogram in patients with precancerous conditions was also noted.
\end{abstract}

Keywords: oral squamous cell carcinoma, leukoplakia, lipids, lipoproteins.

\section{Rola wczesnej diagnostyki raka jamy ustnej}

Raki jamy ustnej stanowią 30\% nowotworów głowy i szyi. Blisko $90 \%$ z nich to raki nabłonkowe kolczystokomórkowe [1]. Szacuje się, że niemal $50 \%$ chorych, u których zdiagnozowano nowotwór, umrze z powodu tej choroby [1]. W ostatnich latach zaobserwowano spadek umieralności spowodowanej wystąpieniem raka jamy ustnej, jednak częstość występowania guzów rośnie, a wskaźnik pięcioletniego przeżycia pozostaje niski [2]. Przebieg choroby jest szczególnie uciążliwy dla pacjentów, a jej leczenie pozostaje wyzwaniem dla klinicystów ze względu na lokalizację zmian w obszarze odpowiedzialnym za szereg czynności fizjologicznych, takich jak mowa, żucie i połykanie [1]. $\mathrm{Na}$ przestrzeni ostatnich lat poszerzył się zakres możliwości terapeutycznych i możliwości poprawy jakości życia chorych na nowotwory jamy ustnej poprzez wprowadzenie nowych technik chirurgicznych i rekonstrukcyjnych. Umieralność pozostaje jednak nadal na wysokim poziomie, ponieważ pacjenci zgłaszają się do lekarza w zaawansowanym stadium choroby [1]. Rozrost nowotworowy często poprzedzony jest wystąpieniem zmian przedrakowych, spośród których najczęściej występuje leukoplakia, opisywana jako biała plama lub płytka na błonie śluzowej jamy ustnej, której nie można usunąć mechanicznie i która nie odpowiada żadnej innej jednostce chorobowej. Leukoplakia jest rozpoznaniem klinicznym, a nie histopatologicznym. Zmiany w nabłonku charakteryzują się hiperkeratozą, parakeratozą, a nawet akantozą. W bardziej zaawansowanym stadium choroby można stwier- 
dzić dysplazję lub carcinoma in situ. Leukoplakia odgrywa szczególną rolę w patogenezie raka jamy ustnej, a ryzyko jej zezłośliwienia określa się na 0,3 do ponad $30 \%$. Do głównych czynników etiologicznych leukoplakii i raka jamy ustnej zalicza się palenie tytoniu i spożywanie alkoholu [3, 4]. W dotychczasowych badaniach wielokrotnie udowodniono, że kluczowe znaczenie dla ostatecznego wyniku leczenia ma jak najwcześniejsze rozpoznanie i leczenie choroby. Wczesna identyfikacja nowotworu jest również określana jako profilaktyka drugorzędowa [3].

\section{Markery biochemiczne w onkologii}

W ostatnich doniesieniach naukowych podkreśla się znaczenie pewnych markerów biochemicznych w płynach ustrojowych, takich jak ślina, krew i mocz, dla wczesnej diagnostyki, prognozowania oraz monitorowania postępu raka i stanów przedrakowych. Zmiany biochemiczne mogą pojawić się $\mathrm{w}$ organizmie pacjenta na długo zanim nowotwór ujawni się klinicznie [5]. Testy wykonywane na podstawie badań krwi są najchętniej wykorzystywane przez klinicystów ze względu na łatwość i powtarzalność badania, małą inwazyjność oraz stosunkowo niski koszt [3].

\section{Funkcje lipidów w organizmie}

Lipidy jako substrat energetyczny, składnik błon komórkowych i prekursor hormonów steroidowych i tkankowych pełnią szereg funkcji biologicznych w organizmie. Uczestniczą między innymi w tworzeniu i podziałach komórek, zarówno fizjologicznych, jak i nowotworowych. W badaniach wykazano, że nadmierna i niekontrolowana proliferacja komórek nowotworowych i ich zwiększone zapotrzebowanie na tłuszcze może skutkować obniżeniem poziomu stężenia lipidów i lipoprotein w osoczu [6-8]. W przebiegu procesu chorobowego w jamie ustnej upośledzone zostaje przyjmowanie pokarmów, więc można przypuszczać, że u chorych z rakiem jamy ustnej poziom lipidów w osoczu będzie obniżony. Udowodniono jednak, że przyjmowanie lipidów z pożywieniem ma niewielki wpływ na ich poziom w osoczu, a istotnie na lipidogram oddziałują czynniki genetyczne i hormony [9].

Cholesterol i trójglicerydy uznane są za najbardziej znaczące klinicznie lipidy osocza. Cholesterol jest głównym składnikiem błon komórkowych, prekursorem hormonów steroidowych i witaminy D, natomiast trójglicerydy jako estry gliceryny i trzech kwasów tłuszczowych są kluczowym źródłem energii [10]. Transport lipidów pomiędzy tkankami odbywa się przy pomocy lipoprotein ze względu na hydrofobową naturę cholesterolu i triglicery- dów. Lipoproteiny zostały podzielone ze względu na gęstość na chylomikrony, lipoproteiny o bardzo małej gęstości (VLDL), lipoproteiny o pośredniej gęstości (IDL), lipoproteiny o małej gęstości (LDL) oraz lipoproteiny o wysokiej gęstości (HDL). Synteza chylomikronów odbywa się w błonie śluzowej jelit z udziałem enterocytów z pobranych z pokarmu cholesterolu i tłuszczów. Cząsteczki VLDL wytwarzane są natomiast w wątrobie $z$ endogennych i egzogennych tłuszczów. Najważniejszą funkcją chylomikronów i VLDL jest transport trójglicerydów do komórek. W naczyniach krwionośnych trójglicerydy znajdujące się $\mathrm{w}$ lipoproteinach hydrolizowane są do wolnych kwasów tłuszczowych, glicerolu i fosfolipidów przez lipazę lipoproteinową związaną z komórkami śródbłonka naczyniowego. Część wolnych kwasów tłuszczowych zostaje zaabsorbowana przez pobliskie komórki, pozostałe zaś łączą się z albuminami osocza i są transportowane dalej [11]. Hydroliza trójglicerydów z VLDL skutkuje powstaniem lipoprotein o pośredniej gęstości, które są hydrolizowane w wątrobie przez lipazę wątrobową do LDL. LDL jest cząsteczką transportującą cholesterol po całym organizmie oraz regulującą syntezę lipidów. Cząsteczka LDL wiązana jest przez receptor, którego aktywność zależy od zapotrzebowania komórek na cholesterol [12]. Nadmiar cholesterolu transportowany jest $z$ powrotem do wątroby przez HDL. Synteza i wydzielanie prekursora HDL zachodzi w wątrobie i jelicie cienkim. Następnie cząsteczka ta krąży w układzie krwionośnym, gdzie łączy się z cholesterolem, tworząc dojrzałą formę HDL, która przenosi cholesterol do wątroby [12].

\section{Oceny poziomu lipidów w osoczu w chorobach układu krążenia, nowotworach i stanach przedrakowych}

Kliniczne znaczenie poziomu lipidów w osoczu w diagnostyce i prognozowaniu przebiegu niektórych chorób jest dobrze udokumentowane. Rola zmieniającego się poziomu tłuszczów w tkankach i krwi pacjentów została szeroko zbadana i opisana w patogenezie i przebiegu choroby niedokrwiennej serca [13]. Wiadomo też, że palenie tytoniu powoduje obniżenie wartości HDL i zwiększenie stężenia trójglicerydów w porównaniu z osobami niepalącymi. Najmniejsze wahania odnotowano w stężeniu cholesterolu całkowitego. Nie stwierdzono wpływu biernego palenia tytoniu na zmiany w lipidogramie [14].

Ostatnie doniesienia naukowe wykazały, że istnieje związek pomiędzy wahaniem poziomu stężenia lipidów w osoczu a występowaniem i przebiegiem niektórych nowotworów złośliwych. W chorobie nowotworowej podwyższona 
aktywność receptora LDL komórek nowotworowych może powodować hipocholesterolemię [15]. $\mathrm{U}$ chorych z rozległym procesem nowotworowym już 2 lata przed postawieniem rozpoznania dochodzi do zaburzeń w metabolizmie lipidów [16]. Najczęściej u pacjentów z rakiem obserwuje się średnio niższy poziom cholesterolu w osoczu niż u osób zdrowych. Rose i wsp. w swoich badaniach z 1980 roku jako pierwsi opisali odwrotną korelację pomiędzy poziomem stężenia cholesterolu we krwi a ryzykiem wystąpienia raka, stwarzając tym samym podstawę do dalszych badań i hipotez na ten temat. Badania Alexopoulosa i wsp. z 1987 roku wykazały, że w przebiegu nowotworów złośliwych, takich jak rak płuca, rak piersi czy białaczki, poziom cholesterolu oraz stężenie LDL we krwi obniża się, a poziom trójglicerydów pozostaje bez zmian. Natomiast stwierdzili, że w przypadku raka piersi występuje wzrost stężenia cholesterolu i LDL, a także trójglicerydów. Autorzy ci sugerowali, że zmiany w lipidogramie w przebiegu nowotworów są jedynie skutkiem, a nie przyczyną choroby [17]. Podobny wniosek $z$ badań przedstawili badacze $\mathrm{z}$ Włoch, stwierdzając, że niski poziom cholesterolu we krwi chorych na raka wydaje się być raczej powiązany ze słabym odżywieniem pacjenta niż konsekwencją rozrostu komórek nowotworowych [18]. Najnowsze doniesienia na temat związku przyczynowo-skutkowego pomiędzy dyslipidemią a występowaniem nowotworów złośliwych są zróżnicowane. Badania Laisupasin i wsp. z 2014 roku wykazały, że zwiększony poziom trójglicerydów i lipoprotein we krwi skutkuje podwyższeniem ryzyka zachorowania na raka piersi u kobiet, natomiast Forones i wsp. opisali obniżony poziom cholesterolu u pacjentów cierpiących na raka jelita grubego jedynie jako konsekwencję wystąpienia choroby [19, 20]. Według badań de Martino i wsp. poziom cholesterolu w osoczu pacjentów przed operacyjnym leczeniem raka nerki jest niezależnym czynnikiem prognostycznym, a niższy jego poziom związany jest z mniejszą przeżywalnością [21].

Większość dotychczasowych badań na temat zmian poziomu lipidów we krwi pacjentów ze stanami przedrakowymi i rakiem jamy ustnej została przeprowadzona w Indiach, gdzie w wyniku powszechnego uzależnienia od wyrobów tytoniowych współczynnik chorobowości i umieralności z powodu tego nowotworu jest jednym z najwyższych na świecie. W 2004 roku Patel i wsp. zbadali 52 zdrowe osoby, 153 ze stanem przedrakowym oraz 184 nieleczonych wcześniej chorych z rakiem głowy i szyi, w większości z rakiem jamy ustnej. Diagnozę postawili na podstawie badania klinicznego i histopatologicznego. Odnotowali znaczący spadek stężenia cholesterolu całkowitego i HDL u pa- cjentów z rakiem i stanami przedrakowymi w jamie ustnej w porównaniu z grupą kontrolną. Średni poziom cholesterolu i HDL był porównywalny w obu grupach badanych. W tym samym badaniu wartości VLDL i trójglicerydów były niższe u pacjentów z rakiem niż u pacjentów ze stanami przedrakowymi i osób zdrowych, ale porównywalne $u$ dwóch ostatnich grup. Badanie poziomu LDL w surowicy nie wykazało znamiennych statystycznie różnic $w$ trzech porównywanych grupach. Kolejnym etapem opisywanego badania było porównanie lipidogramu pomiędzy używającymi i nieużywającymi tytoniu. Analizie poddano również lipidogram osób palących i niepalących w grupie kontrolnej. U zdrowych palących średni poziom lipidów był niższy. Następnie porównano lipidogram chorych i zdrowych. Poziom cholesterolu całkowitego i HDL był niższy u palących z rakiem i stanami przedrakowymi [22]. W roku 2010 Lohe i wsp. po zbadaniu 210 osób (70 zdrowych, 70 z rakiem jamy ustnej i 70 ze stanem przedrakowym) potwierdzili te doniesienia, nie wykazali jednak związku pomiędzy obniżeniem poziomu tłuszczów we krwi a paleniem tytoniu. Dodatkowo podzielili grupę badaną z rakiem jamy ustnej zgodnie ze stopniem zaawansowania histopatologicznego na dobrze zróżnicowany, umiarkowanie zróżnicowany i niskozróżnicowany. Nie zaobserwowali korelacji zmian w lipidogramie ze stopniem zaawansowania nowotworu. W grupie chorych ze stanem przedrakowym, posegregowanych według stopnia dysplazji, również nie znaleźli podobnej korelacji [3]. Singh i wsp. również nie stwierdzili różnic $\mathrm{w}$ lipidogramie $\mathrm{w}$ zależności od stopnia zaawansowania choroby nowotworowej, mimo obniżenia poziomu cholesterolu całkowitego, HDL i trójglicerydów u pacjentów z nowotworem [23]. Chawda i wsp. zbadali 30 osób $(25$ z rakiem jamy ustnej i 5 zdrowych) i odnotowali znaczący spadek stężenia cholesterolu, trójglicerydów i HDL we krwi pacjentów z rakiem jamy ustnej, co jest zgodne z poprzednimi doniesieniami. [5]. Ostatnie badania Kumara i wsp. wskazują na tę samą zależność, autorzy dostrzegają ponadto spadek lipoprotein LDL w przebiegu nowotworu oraz pogłębienie zmian w stężeniu LDL i HDL w procesie transformacji zmiany przednowotworowych $w$ raka [24]. Mehta i wsp. wykazali istotny statystycznie spadek poziomu TC, LDL, HDL, VLDL i trójglicerydów w badanych grupach pacjentów ze stanami przedrakowymi i rakiem jamy ustnej w stosunku do pacjentów z grupy kontrolnej. Ponadto stwierdzili, że poziom badanych wskaźników jest niższy u pacjentów z rakiem niż ze stanami przedrakowymi [6]. Podobne wyniki przedstawili Garg i wsp., ale w grupach badanych zauważyli tylko różnicę w poziomie trójglicerydów i VLDL [8]. Badanie przepro- 
wadzone przez zespół ze Sri Devaraj Urs Medical College w Indiach na 56 osobach, spośród których u 28 rozpoznano raka jamy ustnej, wykazato znamienny statystycznie spadek wartości HDL u pacjentów z rozpoznaną chorobą nowotworową w porównaniu z grupą kontrolną. Odnotowano nieistotny statystycznie wzrost pozostałych parametrów lipidogramu [25]. Do podobnych wniosków doszli wcześniej Nupur i wsp. po zbadaniu 95 osób [26]. W 2015 roku Li i wsp. zmierzyli poziom lipidów u 136 pacjentów z rakiem głowy i szyi oraz u 136 osób zdrowych. W grupie badanej poziom cholesterolu całkowitego i LDL był znacznie niższy, natomiast poziom trójglicerydów i HDL był wyższy, ale nie były to różnice znamienne statystycznie [27]. Ganavi i wsp. potwierdzili te doniesienia tylko w stosunku do cholesterolu całkowitego [28]. Sherubin i wsp. przeprowadzili podobne badanie i wykazali znamienny statystycznie spadek poziomu cholesterolu całkowitego, trójglicerydów, HDL, LDL i VLDL w grupie badanej w porównaniu z grupą kontrolną [29]. Porównywalne wyniki uzyskał Ashutosh po zbadaniu 60 pacjentów z potwierdzonym histopatologicznie rakiem jamy ustnej, zgłaszających się do kliniki laryngologicznej, i 60 zdrowych osób [30]. W 2016 roku Acharya i wsp. opublikowali wyniki badań profilu lipidowego pacjentów z rakiem jamy ustnej i związku z paleniem tytoniu. Grupa badana składała się z 90 nieleczonych wcześniej pacjentów z rakiem kolczystokomórkowym jamy ustnej, a grupa kontrolna z 30 osób zdrowych. Poziom cholesterolu całkowitego, HDL i LDL był niższy w grupie badanej niż w grupie kontrolnej, różnica ta była znamienna statystycznie. Wartości trójglicerydów były również niższe w grupie badanej, ale nie były to różnice statystycznie znamienne. Nie stwierdzono też różnic w lipidogramie u chorych w zależności od zaawansowania procesu nowotworowego, stopnia zróżnicowania histologicznego ani występowania przerzutów do węzłów chłonnych. W grupie badanej u pacjentów używających tytoniu stwierdzono obniżony poziom cholesterolu całkowitego, trójglicerydów i LDL w porównaniu z pacjentami niepalącymi [31].

\section{Podsumowanie}

Lipidy są grupą cząsteczek odpowiedzialnych za gospodarkę energetyczną i budowę komórek. Cholesterol i trójglicerydy pełnią szczególnie ważną rolę w utrzymaniu integralności błon komórkowych i prawidłowym funkcjonowaniu komórek. Lipoproteiny transportują lipidy zarówno do tkanek zdrowych, jak i nowotworowych, więc ich rola w rozwoju raka jest istotna. Dostarczają lipidy do komórek nowotworowych, które z powodu szybkiego wzrostu i proliferacji potrzebują znacz- nych ilości substratów energetycznych i składników błon komórkowych. Niektórzy autorzy badań zwracają uwage na zmiany $w$ profilu lipidowym w przebiegu raka różnych narządów, w tym raka jamy ustnej. W badaniach opisywane są niższe wartości lipidów i lipoprotein w surowicy chorych na raka niż u pacjentów zdrowych. Zauważono też obniżenie poziomu cholesterolu całkowitego i HDL u pacjentów ze stanami przedrakowymi. Większość badaczy uważa, że zaburzenia w profilu lipidowym u pacjentów z rakiem jamy ustnej są konsekwencją procesu chorobowego, a nie jego przyczyną, mimo że w poprzednich doniesieniach występowały sprzeczne opinie na ten temat. Autorzy publikacji zgodnie podkreślają, że istnieje pilna potrzeba przeprowadzenia dalszych badań na temat wartości diagnostycznej i prognostycznej analizy poziomu lipidów we krwi dla wczesnego wykrywania i leczenia raka jamy ustnej.

\section{Oświadczenia}

Oświadczenie dotyczące konfliktu interesów

Autorzy deklarują brak konfliktu interesów w autorstwie oraz publikacji pracy.

\section{Źródła finansowania}

Autorzy deklarują brak źródeł finansowania.

\section{Piśmiennictwo}

[1] Miloro M, Ghali GE, Larsen P, Waite P. Peterson's Principles of Maxillofacial Surgery. PMPH-USA 2012. s. 617630.

[2] Issa B, Padilla R, Brennan M.T. Diagnosis and Management of Mucosal Lesions with the Potential for Malignant Tranformation. Journal of the California Dental Association. 2013 May;41(5):343-8.

[3] Lohe VK, Degwekar SS, Bhowate RR, Kadu RP, Dangore S.B. Evaluation of correlation of serum lipid profile in patients with oral cancer and precancer and its association with tobacco abuse. J Oral Pathol Med. 2010;39:141-8.

[4] WHO Collaborating Centre for Oral Precancerous Lesions. Definition of leukoplakia and related lesions: an aid to studies on oral precancer. Oral Surg Oral Med Oral Pathol. 1978;46:518-539.

[5] Chawda JG, Jain SS, Patel HR, Chaduvula N, Patel K. The relationship between serum lipid levels and the risk of oral cancer. Indian J Med Paediatr Onc. 2011;32(1):34-7.

[6] Mehta R, Gurudath S, Dayansoor S, Pai A, Ganapathy K.S. Serum lipid profile in patients with oral cancer and precancerous conditions. Dent Res J 2014 May-Jun; 11(3): 345-350.

[7] Neville BW, Day T.A. Oral Cancer and Precancerous Lesions. CA Cancer J Clin. 2002;52: 195-215.

[8] Garg D, Sunil MK, Singh PP, Singla N, Ashwini Rani SR, Kaur B. Serum lipid profile in oral precancer and cancer: a diagnostic or prognostic marker? J Int Oral Health. 2014; 6(2):33-39.

[9] Munir R, Usman H, Hasnain S, Smans K, Kalbacher H, Zaidi N. Atypical plasma lipid profile in cancer patients: cause or consequence. Biochimie. 2014;102:9-18.

[10] Hegele R.A. Plasma lipoproteins: genetic influences and clinical implications. Nat Rev Genet. 2009 Feb;10(2):109-21.

[11] Vance JE, Vance D.E. Biochemistry of Lipids, Lipoproteins and Membranes. Elsevier Science, 2008.

[12] Murray RK, Granner DK, Mayes PA, Rodwell V.W. Biochemia Harpera. PZWL, Warszawa; 1995. s. 294-328. 
[13] Grundy S.M. Obesity, metabolic syndrome, and cardiovascular disease, J. Clin. Endocrinol. Metab. 2004;89:25952600.

[14] Zielińska- Danch W, Czogała J, Sobczak A, Grela W, Gnyp W. Stopień narażenia na dym tytoniowy a profil lipidowy. Przegląd Lekarski. 2008;65(10):500-504.

[15] Vitols S, Gahrton G, Bjorknoln M, Peterson C. Hypocholesterolemia in malignancy due to elevated lowdensity-lipoprotein-receptor activity in tumor cells: Evidence from studies in patients with leukaemia. Lancet. 1985; 2: I 150I 154.

[16] Kritchevsky SB, Wilcosky TC, Morris DL, Truong KN, Tyroler H.A. Changes in plasma lipid and lipoprotein cholesterol and weight prior to the diagnosis of cancer. Cancer Res. 1991;51:3198-3203.

[17] Alexopoulos CG, Blastios B, Avgerinos A. Serum lipids and lipoprotein disorders in cancer patients. Cancer. 1987;60:3065-70.

[18] Fiorenza AM, Branchi A, Cardena A, Molgora M, Rovellini A, Sommariva D. Serum cholesterol levels in patients with cancer. Int J Clin Lab Res. 1996;26:37-42.

[19] Laisupasin P, Warayupa T, Sukarayodhin S, Sornprom A, Sudjaroen Y. Comparison of serum lipid profiles between normal controls and breast cancer patients. J Lab Physicians. 2013 Jan;5(1):38-41.

[20] Forones NM, Falcao JB, Mattos D, Barone B. Cholesterolemia in colorectal cancer. Hepatogastroenterology. 1998 Sep-Oct;45(23):1531-4.

[21] de Martino M, Leitner CV, Seemann C, Hofbauer SL, Lucca I, Haitel A, Shariat SF, Klatte T. Preoperative serum cholesterol is an independent prognostic factor for patients with renal cell carcinoma (RCC). British Journal of Cancer. 2014;111(8):1526-1531.

[22] Patel PS, Shah MH, Jha FP, Raval GN, Rwala RM, Patel MM, Patel JB, Patel D.D. Alterations in plasma lipid profile patterns in head and neck cancer and oral precancerous conditions. Indian J Cancer. 2004;41(1):25-31.

[23] Singh S, Ramesh V, Premalatha B, Prashad KV, Ramadoss $\mathrm{K}$. Alterations in serum lipid profile patterns in oral cancer. J Nat Sci Biol Med. 2013;4(2):374-378.

[24] Kumar P, Augustine J, Urs AB, Arora S, Gupta S, Mohanty V.R. Serum lipid profile in oral cancer and leukoplakia: correlation with tobacco abuse and histological grading. J Cancer Res Ther. 2012 Jul-Sep;8(3):384-8.

[25] Kamath A, Shashidhar KN, Anantharamaiah H, Rangareddy H, Sathyanarayana VB. Risk factors, lipid profile, and histopathological study of oral cancers in Kolar district: A case-control study. J Can Res Ther. 2014;10:171-5.

[26] Nupur G, Ravi Prakash SM, Sankalp V, Soumi G, Neha A, Navin S. Alterations in serum lipid profile patterns in head \& neck cancer and oral submucous fibrosis patients. Int Dent J Stud Res. 2014;2(3):17-24.

[27] Li G, Da M, Zhang W, Wu H, Ye J, Chen J, Ma L, Gu N, Wu $Y$, Song $X$. Alteration of serum lipid profile and its prognostic value in head and neck squamous cell carcinoma. J Oral Pathol Med. 2016;45:167-172.

[28] Ganavi BS, Patil S, Rao RS. Evaluation of serum lipids and lipoproteins as prognosticators in leukoplakia. J Contemp Dent Pract. 2014;15(3):294-299.

[29] Sherubin EJ, Kannan KS, Kumar DN, Joseph I. Estimation of plasma lipids and its significance on histopathological grades in oral cancer: Prognostic significance an original research. J Oral Maxillofac Pathol. 2013;17:4-9.

[30] Ashutosh K. Relationship between serum lipid profile and oral squamous cell carcinoma. Int J Dent Health Sci. 2015;2(1):22-26.

[31] Acharya S, Rai P, Hallikeri K, Anehosur V, Kale J. Serum lipid profile in oral squamous cell carcinoma: alterations and association with some clinicopathological parameters and tobacco use. Int. J Oral Maxillofac Surg. 2016;45: 713-720.

Zaakceptowano do edycji: 2017-09-01 Zaakceptowano do publikacji: 2017-11-02

\section{Adres do korespondencji:}

Klinika Chirurgii Czaszkowo-Szczękowo-Twarzowej,

Chirurgii Jamy Ustnej i Implantologii

Warszawski Uniwersytet Medyczny

Kampus Lindleya

ul. Lindleya 4 pawilon 4, 02-005 Warszawa

tel.: +48601344101

e-mail: andrzejkolciuk@gmail.com 